\title{
Integrated Management of Gummy Stem Blight of Watermelon by Green Manure and Melcast- scheduled Fungicides
}

Xin-Gen Zhou and Kathryne L. Everts, University of Maryland College Park, Lower Eastern Shore Research and Education Center, Salisbury, MD 21801. K. L. Everts has a joint appointment with the University of Delaware, Georgetown, DE 19947

Corresponding author: K. L. Everts. keverts@umd.edu

Zhou, X.-G., and Everts, K. L. 2008. Integrated management of gummy stem blight of watermelon by green manure and Melcast-scheduled fungicides. Online. Plant Health Progress doi:10.1094/PHP-2008-1120-01-RS.

\begin{abstract}
Watermelon gummy stem blight (GSB) management using a green manure cover crop, the weather-based disease forecasting program 'Melcast,' and bio- and reduced-risk fungicides was evaluated in Maryland. Soil incorporation of hairy vetch winter cover crop suppressed percent foliage affected by GSB in comparison to winter fallow in three of five trials conducted in 2004 and 2005. Programs of Reynoutria sachalinensis, Bacillus subtilis, or harpin protein applied in rotation with chlorothalonil provided control of GSB as effectively as did EBDC, boscalid, or cyprodinil plus fludioxonil. However, the bio-fungicide programs did not perform as well as chlorothalonil alternated with pyraclostrobin plus boscalid in 2005. Melcast-scheduled sprays of $\mathrm{B}$. subtilis in rotation with chlorothalonil resulted in an average of $73 \%$ less synthetic fungicide applied to watermelon. However, GSB reduction in the $B$. subtilis program, although similar in 2005, was less that that obtained with chlorothalonil alone in 2004 . These results suggest that the combined use of green manure with Melcast-scheduled fungicide applications could effectively manage GSB and reduce fungicide use. Biofungicides alternated with chlorothalonil also minimized use of synthetic fungicides and were effective under some conditions, but should be used with caution.
\end{abstract}

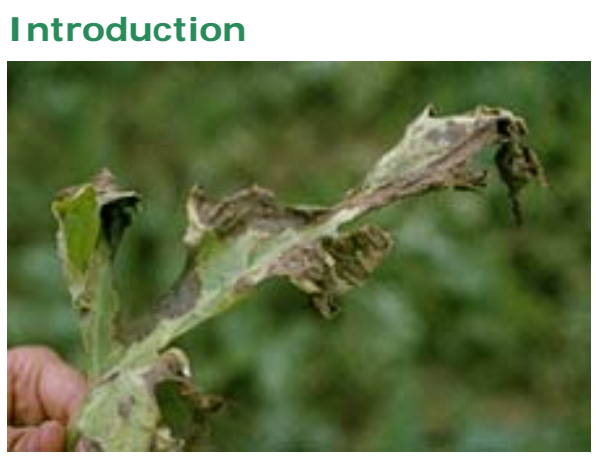

Fig. 1. A leaf of watermelon showing typical symptoms of gummy stem blight, caused by Didymella bryoniae.
Gummy stem blight (GSB), caused by Didymella bryoniae (Auersw.) Rehm (Fig. 1, 2, and 3), is the most common and destructive foliar disease of watermelon [Citrullus lanatus (Thunb.) Matsum. \& Nakai] in the southeastern United States. Crop rotation, which is widely practiced to reduce initial inoculum, does not prevent severe outbreaks when weather is conducive to disease development (Fig. 4). Genetic resistance is not widely deployed (9); therefore, growers rely on multiple applications of fungicides (six

to ten per year in the mid-Atlantic) to limit yield loss due to GSB. More fungicides are applied to watermelon than insecticides and herbicides, accounting for more than $65 \%$ of total chemicals used annually on watermelon in the United States (2). Although there are several registered fungicides for GSB, many are members of common fungicide resistance action (FRAC) groups that have a high risk of resistance development. Resistance in D. bryoniae has been found to the FRAC group 1, benzimidazole fungicides; FRAC group 11, quinone outside inhibitors; and most recently to boscalid, FRAC group 7 $(6,11,19)$. Because D. bryoniae has developed resistance to many fungicides, the development of integrated programs that reduce the use of synthetic fungicides 
may benefit watermelon growers, increasing the time fungicides are effective by reducing selection pressure.

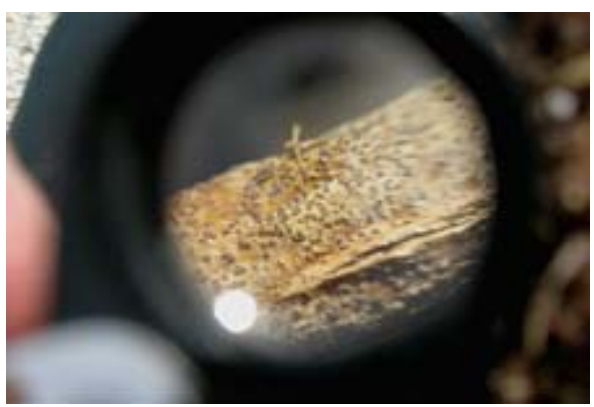

Fig. 2. Pycnidia of Didymella bryoniae on a watermelon seedling stem examined with a $14 \times$ hand lens.

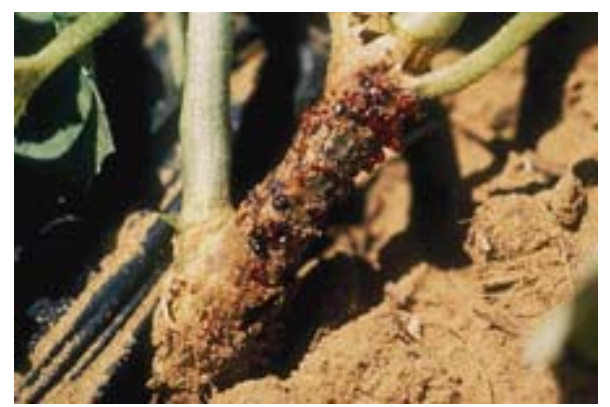

Fig. 3. A stem of watermelon showing the gummy exudate symptoms of gummy stem blight, caused by Didymella bryoniae (courtesy of R. X. Latin, Purdue University).

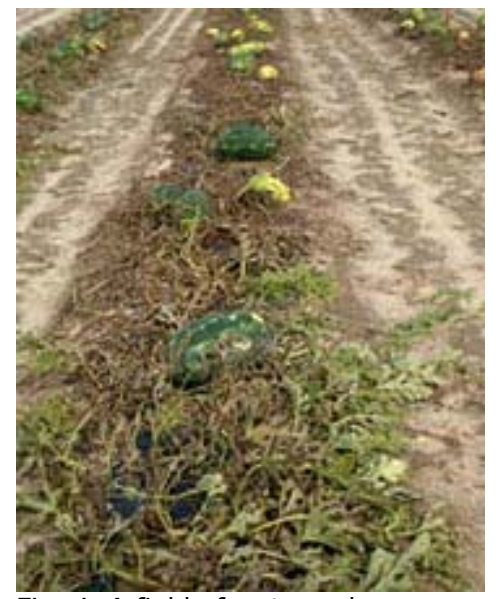

Fig. 4. A field of watermelon showing a severe outbreak of gummy stem blight, caused by Didymella bryoniae.

Cover crops are a potential management technique; recent research demonstrated a reduction of disease on some crops following cover crop use $(4,7,10,16,20)$. Soil-incorporated cabbage residue along with solarization significantly reduced severity of GSB and increased fruit yield of watermelon (10). A hairy vetch (Vicia villosa Roth) cover crop that was killed in the spring and left as residue on the soil surface decreased foliar diseases on fresh tomato (16) and foliar and fruit disease on pumpkin (7).

Biofungicides also may provide an additional tool for management of GSB on watermelons. Commercially available biofungicides include Bacillus subtilis (Serenade), B. pumilis (Sonata), Reynoutria sachalinensis (Milsana), chitosan (Elexa), and harpin protein (Messenger). Biofungicides, especially in alternation with chlorothalonil, did provide some suppression of GSB, anthracnose (Colletotrichum orbiculare), downy mildew (Pseudoperonospora cubensis), and powdery mildew (Podosphaera xanthii) on cucurbits although not consistently $(3,5,13,14)$.

Fungicide use on watermelon and muskmelon has been reduced with a disease forecasting program, Melcast (melon disease forecaster) $(8,14)$. Melcast was developed for scheduling applications of fungicides for control of anthracnose and GSB on watermelon based on weather conditions $(15,17)$. Briefly, the number of hours of leaf wetness and the temperature during periods of leaf wetness (17) are used to identify conditions that favor disease development and to advise fungicide application. Melcast, which was developed in Indiana, has been tested and used on research and commercial cucurbits in Delaware, Georgia, Indiana, Iowa, and Maryland $(8,14)$. Melcast resulted in a 
reduction in fungicide use for watermelon by 10 to 20\% (15). Although Melcast has provided a similar level of disease management to weekly sprays when conventional fungicides were used, it has never been tested using biofungicides.

The objective of this study was to develop integrated management programs for GSB on watermelon in the mid-Atlantic by: (i) assessing the influence of hairy vetch green manure; (ii) evaluating biofungicides and reduced-risk fungicides in rotation with chlorothalonil applied according to Melcast; and (iii) evaluating green manure in combination with Melcast and Bacillus subtilis.

\section{General Practices}

All trials were conducted at the University of Maryland's Lower Eastern Shore Research and Education Center, Salisbury in fields where watermelon had been cropped in rotation for many years and which had a high level of GSB inoculum. Plots consisted of single rows, $1.8 \mathrm{~m}$ apart, with $15 \mathrm{~cm}$ high beds covered with black polyethylene. Four week-old greenhouse grown seedlings were transplanted $0.9 \mathrm{~m}$ apart within the rows. Fallow plots were fertilized based on soil tests. Hairy vetch plots were fertilized based on the estimated contribution of hairy vetch biomass and $\mathrm{N}$ content (biomass in three $1 \mathrm{~m}^{2}$ areas of each plot was weighed prior to incorporation).

GSB was rated as percent of symptomatic foliage using a modified HorsfallBarratt scale (12) and converted to percent severity prior to analysis. The disease data were subjected to analysis of variance using the mixed procedure and multiple comparisons were calculated using Scheffe's test (green manure fungicide timing trials) and Fisher's protected least significance differences (LSDs, green manure, and efficacy trials). Analyses for all trials in this study were performed using the Statistical Analysis System (version 8.2, SAS Institute Inc., Cary, NC).

\section{Green Manure Trials}

Green manure trials were conducted in two fields (17B and 17A) in 2004 and one field (17A) in 2005. In 2004, the experiment in 17B was conducted as a split plot design with four replications. Whole plots consisted of two cover crop treatments (winter fallow and hairy vetch winter cover crop); and subplots consisted of two triploid (seedless) watermelon cultivars (Millionaire and Seedless Sangria). The experiment conducted in 17A in 2004 and 2005 was a randomized complete block design. The two cover crop treatments were randomly arranged into each of four blocks and cv. Millionaire was planted. In each experiment, plots were $25 \mathrm{~m}$ long. Hairy vetch was seeded at $45 \mathrm{~kg} / \mathrm{ha}$ in early October, and was killed by an application of paraquat (Gramoxone Extra 2.5SC, $1.2 \mathrm{~kg}$ ai/ ha) late May and disked three times into the soil to a depth of 15 to $20 \mathrm{~cm}$. Winter fallow plots received the same treatment of herbicide and soil incorporation. Seedlings of triploid watermelon were transplanted in middle J une and seedlings of the diploid watermelon cv. Royal Majesty were transplanted at every third row as a plot border and served as the pollinator. GSB was rated seven weeks after transplanting as described previously.

In 2004, hairy vetch green manure significantly reduced percent foliage affected by GSB at site 17B, but not at site 17A where the disease pressure was very high (Table 1). In 2005, the green manure significantly suppressed severity of GSB. 
Table 1. Effect of hairy vetch green manure on percent foliage affected by gummy stem blight on watermelon in 2004 and 2005.

\begin{tabular}{|l|c|c|c|c|}
\hline \multirow{2}{*}{ Year } & \multirow{2}{*}{ Trial site } & Winter fallow & Hairy vetch & Reduction $^{\mathrm{x}}$ \\
\cline { 3 - 5 } & $17 \mathrm{~B}$ & $28^{\mathrm{y}}$ & 16 & $43^{*}$ \\
\hline 2004 & $17 \mathrm{~A}$ & 98 & 88 & 10 \\
\cline { 2 - 5 } & $17 \mathrm{~A}$ & 56 & 23 & $59 *$ \\
\hline 2005 & & &
\end{tabular}

${ }^{\mathrm{x}}$ Reduction $(\%)=($ Fallow - Vetch $) /$ Fallow $\times 100$. Values with asterisks $(*)$ indicate that the hairy vetch treatment is significantly $(P=0.05)$ different from the fallow treatment according to Fisher's protected LSD test.

$y$ Means were the average of the four replicated plots. For the trial conducted at $17 B$ in 2004, means represent the combined data across two watermelon cultivars evaluated, because there were no significant effects of cultivar $(P \geq 0.5075)$ nor green manure and cultivar interactions $(P \geq 0.7528)$.

\section{Fungicide Efficacy Trials}

The efficacy of ten fungicide or biofungicide treatments (Table 2) was evaluated in 14-m long plots in 2004 and 2005. Seedlings of the diploid watermelon cv. J amboree, were transplanted on 21 May 2004 and 2 J une 2005. Treatments were randomly arranged into each of four complete blocks. Fungicides were applied with a tractor-mounted sprayer that delivered 421 liter/ ha at 296 Kpa through a boom with six D4 45 hollow cone nozzles. First application was initialized when the vines met within the row except harpin protein applications that began 18 May 2004 on transplants in the greenhouse (Table 2). Subsequent applications were scheduled according to Melcast, which triggered a spray following the accumulation of 30 Environmental Favorability Indices (EFI) after the preceding application (15). Site-specific leaf wetness and temperature data that generated EFIs for Melcast were purchased from Skybit Inc. (Boalsburg, PA). In addition, two EFI values were added when overhead irrigation was applied. GSB was rated on 27J uly in 2004 and 16 August in 2005 as described previously (12).

In 2004 and 2005, a total of five and six sprays were applied based on Melcast, respectively. Severity of GSB was low in 2004 and a late season epidemic of downy mildew killed foliage in nontreated plots by 5 August. In 2005, GSB severity was high. GSB was significantly reduced compared to the nontreated plots, by all biofungicides and fungicide schedules in both years. B. subtilis (tested in 2005 only), R. sachalinensis, and harpin protein applied in rotation with chlorothalonil reduced GSB compared to the unsprayed plots, comparable to consecutive applications of chlorothalonil, boscalid, EBDC followed by chlorothalonil, and chlorothalonil alternated with cyprodinil plus fludioxonil (Table 2). However, only chlorothalonil alternated with $\mathrm{R}$. sachalinensis, and only when disease was low in 2004, performed as well as the best treatment, which was chlorothalonil alternated with pyraclostrobin plus boscalid.

In 2004, chlorothalonil in alternation with pyraclostrobin plus boscalid ranked lowest in GSB, but was not significantly better than chlorothalonil alternated with cyprodonil plus fludioxonil, cyprodonil or boscalid or chlorothalonil alone. However, when GSB severity was higher in 2005, chlorothalonil in alternation with pyraclostrobin plus boscalid resulted in significantly lower GSB than all other fungicide treatments except chlorothalonil alone. 
Table 2. Efficacy of biofungicides and synthetic fungicides in alternation with chlorotahlonil applied based on Melcast for controlling gummy stem blight (GSB) of watermelon in 2004 and 2005.

\begin{tabular}{|c|c|c|c|c|}
\hline \multirow[b]{2}{*}{ Treatment $^{\mathrm{V}}$} & \multicolumn{2}{|l|}{2004} & \multicolumn{2}{|c|}{2005} \\
\hline & $\begin{array}{c}\text { Application } \\
\text { timing }^{\mathrm{W}}\end{array}$ & $\begin{array}{l}\text { GSB } \\
(\%)^{x}\end{array}$ & $\begin{array}{l}\text { Application } \\
\text { timing }\end{array}$ & $\begin{array}{l}\text { GSB } \\
(\%)\end{array}$ \\
\hline Chlorothalonil & $1-5$ & $6.0 \mathrm{bcd}^{\mathrm{Y}}$ & $1-6$ & $33.5 \mathrm{~cd}$ \\
\hline $\begin{array}{l}\text { Chlorothalonil }+ \\
\text { cyprodinil plus fludioxonil }\end{array}$ & $\begin{array}{c}1,3,5+ \\
2,4\end{array}$ & $4.0 \mathrm{bcd}$ & $\begin{array}{c}1,3,5+ \\
2,4,6\end{array}$ & $47.5 \mathrm{c}$ \\
\hline $\begin{array}{l}\text { Chlorothalonil + } \\
\text { boscalid }\end{array}$ & $\frac{-{ }^{z}+}{1-5}$ & $5.3 \mathrm{bcd}$ & $\begin{array}{c}1,3,5+ \\
2,4,6\end{array}$ & $48.5 \mathrm{c}$ \\
\hline $\begin{array}{l}\text { Chlorothalonil + } \\
\text { cyprodinil }\end{array}$ & $\begin{array}{c}1,3,5+ \\
2,4\end{array}$ & $3.5 \mathrm{~cd}$ & $\begin{array}{c}1,3,5+ \\
2,4,6\end{array}$ & 54.5 bc \\
\hline $\begin{array}{l}\text { Chlorothalonil }+ \\
\text { harpin protein }\end{array}$ & $\begin{array}{c}1,3,5+ \\
\text { tray, seedling, } 2,4\end{array}$ & $8.5 \mathrm{~b}$ & - & - \\
\hline $\begin{array}{l}\text { Chlorothalonil + } \\
\text { B. subtilis }\end{array}$ & - & - & $\begin{array}{c}1-6+ \\
1-6\end{array}$ & $55.0 \mathrm{bc}$ \\
\hline $\begin{array}{l}\text { Chlorothalonil + } \\
\text { chitosan }\end{array}$ & $\begin{array}{c}1,3,5+ \\
2,4\end{array}$ & $8.5 \mathrm{~b}$ & $\begin{array}{c}1,3,5+ \\
2,4,6\end{array}$ & $71.5 \mathrm{~b}$ \\
\hline $\begin{array}{l}\text { Chlorothalonil + } \\
\text { R. sachanilensis }\end{array}$ & $\begin{array}{c}1,3,5+ \\
2,4\end{array}$ & $5.5 \mathrm{bcd}$ & $\begin{array}{c}1,3,5+ \\
2,4,6\end{array}$ & $50.0 \mathrm{bc}$ \\
\hline $\begin{array}{l}\text { Chlorothalonil }+ \\
\text { pyraclostrobin plus boscalid }\end{array}$ & $\begin{array}{c}1,3,5+ \\
2,4\end{array}$ & $2.0 \mathrm{~d}$ & $\begin{array}{c}1,3,5+ \\
2,4,6\end{array}$ & $19.25 \mathrm{~d}$ \\
\hline $\begin{array}{l}\text { EBDC }+ \\
\text { chlorothalonil }\end{array}$ & $\begin{array}{c}1,2,3+ \\
4,5\end{array}$ & $8.5 \mathrm{~b}$ & $\begin{array}{c}1,2,3+ \\
4,5,6\end{array}$ & $52.5 \mathrm{bc}$ \\
\hline Nontreated control & & $21.3 \mathrm{a}$ & & $94.3 \mathrm{a}$ \\
\hline
\end{tabular}

${ }^{\vee}$ Chlorothalonil (Bravo Ultrex 82.5 WDG, $2.50 \mathrm{~kg}$ ai/ha); pyraclostrobin plus boscalid (Pristine 38 WG, $0.39 \mathrm{~kg}$ ai/ha); boscalid (Endura $70 \mathrm{WG}, 0.29 \mathrm{~kg}$ ai/ha); cyprodinil plus fludioxonil (Switch 62 WG, $0.61 \mathrm{~kg}$ ai/ha); cyprodinil (Vangard 75 WG, $0.26 \mathrm{~kg}$ ai/ha in 2004 and $0.37 \mathrm{~kg}$ ai/ha in 2005); EBDC (Manzate 75 DF, $2.80 \mathrm{~kg}$ ai/ha); chitosan (Elexa 4CS, 9 pt/acre); Reynoutria sachalinensis (Milsana, giant knotweed extract, 1.87 liter/ha, plus Kinetic as adjuvant, 0.80 liter/ha); and Bacillus subtilis (Serenade ASO, 0.70 liter ai/ha, plus Biotune as adjuvant, $2 \% \mathrm{v} / \mathrm{v}$ ).

${ }^{\mathrm{w}}$ Application dates were: in 2004, tray $=18$ May, seedling $=4$ Jun, $1=9$ Jun, $2=23 \mathrm{Jun}, 3=6 \mathrm{Jul}, 4=16 \mathrm{Jul}$, and $5=29 \mathrm{Jul}$; and in 2005, $1=23 \mathrm{Jun}$, $2=5 \mathrm{Jul}, 3=12 \mathrm{Jul}, 4=19 \mathrm{Jul}, 5=1 \mathrm{Aug}$, and $6=10 \mathrm{Aug}$.

$x$ Percent foliage affected by GSB on 27 July 2004 and 16 August 2005.

$y$ Means within column followed the same letter are not significantly different $(P=0.05)$ according to Fisher's protected LSD test.

$\mathrm{z} " \mathrm{-}=$ = not tested.

\section{Green Manure and Melcast-Based Fungicide Trials}

An experiment to evaluate green manure, Melcast, and a biofungicide program used in combination also was conducted in 2004 and 2005. Twelve treatments were arranged as a split plot design with four replications. The main plot treatments were a cover crop of hairy vetch that was killed in the spring and amended to soil as a green manure, or winter fallow (nonamended control). Subplots consisted of six treatments: (i) Melcast-scheduled applications of B. subtilis alternated with chlorothalonil; (ii) Melcast-scheduled applications of chlorothalonil alone; (iii) weekly applications of B. subtilis alternated with chlorothalonil; (iv) weekly applications of chlorothalonil alone; (v) weekly applications of chlorothalonil in rotation with pyraclostrobin plus boscalid; or (vi) no-fungicide control (Tables 3 and 4). Hairy vetch was seeded at $34 \mathrm{~kg} / \mathrm{ha}$ in each year, and all other procedures were similar to the green manure trials. The watermelon cv. J amboree was used in each year. Fungicide application began when the vines met within the row and subsequent applications were applied weekly or scheduled according to Melcast as described in the fungicide efficacy trials. Severity of GSB was assessed using the same method as described previously. For statistical analysis, the reduction in disease in treated plots 
compared to the severity in nontreated fallow plots was calculated. Three planned contrasts were conducted (Table 3).

Table 3. Variance analysis for the effects of hairy vetch green manure and fungicide application on foliar disease reduction and yield of watermelon in 2004 and 2005 in comparison to the fallow plots with no-fungicide applied.

\begin{tabular}{|c|c|c|c|c|c|}
\hline \multirow{2}{*}{\multicolumn{3}{|c|}{\begin{tabular}{|l} 
\\
Source
\end{tabular}}} & \multicolumn{2}{|c|}{$\begin{array}{c}\text { Gummy stem blight } \\
\text { reduction }\end{array}$} & \multirow{3}{*}{$\begin{array}{c}\begin{array}{c}\text { Marketable } \\
\text { fruit yield }\end{array} \\
0.0423\end{array}$} \\
\hline & & & \multirow{2}{*}{\begin{tabular}{|c|} 
Rating $\mathbf{1}^{\mathrm{x}}$ \\
0.2910
\end{tabular}} & \multirow{2}{*}{$\frac{\text { Rating } 2}{0.4446}$} & \\
\hline \multirow[t]{6}{*}{2004} & \multicolumn{2}{|c|}{ Green manure } & & & \\
\hline & \multicolumn{2}{|l|}{ Fungicide } & $<0.0001$ & $<0.0001$ & 0.0550 \\
\hline & \multirow[t]{3}{*}{$\begin{array}{l}\text { Planned } \\
\text { contrasts }{ }^{y}\end{array}$} & $\begin{array}{l}\text { Weekly fungicide vs. } \\
\text { Melcast-scheduled } \\
\text { applications }\end{array}$ & 0.0703 & 0.1103 & 0.3593 \\
\hline & & $\begin{array}{l}\text { Chlorothalonil vs. } \\
\text { Bacillus subtilis alt. } \\
\text { chlorothalonil }\end{array}$ & 0.0545 & 0.0007 & 0.9520 \\
\hline & & $\begin{array}{l}\text { Chlorothalonil vs. } \\
\text { pyraclostrobin + } \\
\text { boscalid alt. } \\
\text { chlorothalonil }\end{array}$ & 0.9121 & 0.2880 & 0.1091 \\
\hline & \multicolumn{2}{|c|}{ Green manure $\times$ fungicide } & 0.6528 & 0.3456 & 0.7365 \\
\hline \multirow[t]{6}{*}{2005} & \multicolumn{2}{|c|}{ Green manure } & 0.7870 & 0.0064 & 0.0929 \\
\hline & \multicolumn{2}{|l|}{ Fungicide } & $<0.0001$ & 0.0003 & 0.5230 \\
\hline & \multirow[t]{3}{*}{$\begin{array}{l}\text { Planned } \\
\text { contrasts }\end{array}$} & $\begin{array}{l}\text { Weekly fungicide vs. } \\
\text { Melcast-scheduled } \\
\text { applications }\end{array}$ & 1.000 & 0.1825 & 0.1818 \\
\hline & & $\begin{array}{l}\text { Chlorothalonil vs. } \\
\text { Bacillus subtilis alt. } \\
\text { chlorothalonil }\end{array}$ & 0.5914 & 0.4368 & 0.7480 \\
\hline & & $\begin{array}{l}\text { Chlorothalonil vs. } \\
\text { pyraclostrobin + } \\
\text { boscalid alt. } \\
\text { chlorothalonil }\end{array}$ & 0.1353 & 0.8064 & 0.3868 \\
\hline & \multicolumn{2}{|c|}{ Green manure $\times$ fungicide } & 0.3721 & 0.3638 & 0.2974 \\
\hline
\end{tabular}

$\times$ Rating 1 was on 16 Jul 2004, and 5 Aug 2005;

Rating 2 was on 27 Jul 2004 and 17 Aug 2005.

Y Planned contrasts: Weekly fungicides were chlorothalonil (Bravo Ultrex 82.5WDG, $2.50 \mathrm{~kg} \mathrm{ai} / \mathrm{ha}$ ) or Bacillus subtilis (Serenade 10WP, $0.4 \mathrm{~kg}$ ai/ha) alternated with chlorothalonil applied every 7 days; Melcast-scheduled applications were chlorothalonil or Bacillus subtilis alternated with chlorothalonil applied when the Environmental Favorability Indices reached 30, or every 14 days, whichever came first. Application dates were: in 2004, weekly $=16,23$, and $30 \mathrm{Jun}, 7,15,22$, and $30 \mathrm{Jul}$, and 9 Aug; Melcast $=16$ and 30 Jun, 20 and $30 \mathrm{Jul}$, and 9 Aug; and in 2005, weekly = 23 Jun, 5, 12, 19, and 27 Jul, 2 and 9 Aug; Melcast = 5, 12, and 19 Jul, 1 and 10 Aug. 
Table 4. Comparison of the effect of chlorothalonil or Bacillus subtilis alternated with chlorothalonil applied weekly or according to the weather-based spray application model Melcast on gummy stem blight and yield.

\begin{tabular}{|c|c|c|c|c|c|c|}
\hline \multirow{3}{*}{$\begin{array}{l}\text { Fungicides } \\
\text { (and schedule) } y\end{array}$} & \multicolumn{3}{|c|}{2004} & \multicolumn{3}{|c|}{2005} \\
\hline & \multicolumn{2}{|c|}{$\begin{array}{c}\text { Gummy stem } \\
\text { blight reduction } \\
(\%)^{x} \\
\end{array}$} & \multirow{2}{*}{$\begin{array}{l}\text { Yield } \\
(\mathrm{MgHa})\end{array}$} & \multicolumn{2}{|c|}{$\begin{array}{l}\text { Gummy stem } \\
\text { blight reduction } \\
(\%)\end{array}$} & \multirow{2}{*}{$\begin{array}{l}\text { Yield } \\
(\mathrm{MgHa})\end{array}$} \\
\hline & $16 \mathrm{Jul}$ & $27 \mathrm{Jul}$ & & 5 Aug & 17 Aug & \\
\hline Nontreated & $0 b^{z}$ & $0 \mathrm{c}$ & $50.7 \mathrm{a}$ & $-9 b$ & $8 \mathrm{~b}$ & $46.8 \mathrm{a}$ \\
\hline Chlorothalonil (weekly) & $79 \mathrm{a}$ & $94 \mathrm{a}$ & $54.7 \mathrm{a}$ & $83 a$ & $57 \mathrm{a}$ & $47.2 \mathrm{a}$ \\
\hline Chlorothalonil (Melcast) & $73 a$ & $92 a b$ & $58.5 \mathrm{a}$ & 75 a & $50 \mathrm{a}$ & $48.8 \mathrm{a}$ \\
\hline $\begin{array}{l}\text { Bacillus subtilis alt. } \\
\text { chlorothalonil (weekly) }\end{array}$ & $73 a$ & $87 a b$ & $56.8 \mathrm{a}$ & $71 \mathrm{a}$ & $54 a$ & $46.3 \mathrm{a}$ \\
\hline $\begin{array}{l}\text { B. subtilis alt. } \\
\text { chlorothalonil (Melcast) }\end{array}$ & $58 a$ & $82 \mathrm{~b}$ & $56.6 \mathrm{a}$ & 79 a & $41 a b$ & $48.7 \mathrm{a}$ \\
\hline $\begin{array}{l}\text { Pyraclostrobin plus } \\
\text { boscalid alt. } \\
\text { chlorothalonil (weekly) }\end{array}$ & $80 \mathrm{a}$ & $97 \mathrm{a}$ & $59.3 \mathrm{a}$ & $68 \mathrm{a}$ & $54 a$ & $45.4 \mathrm{a}$ \\
\hline
\end{tabular}

$\times$ Means are averaged over main plots (hairy vetch green manure and fallow). Gummy stem blight reduction is the percent reduction in gummy stem blight compared to gummy stem blight in the non-fungicide treated fallow plots.

$y$ Formulations and rates of fungicides were chlorothalonil applied as Bravo Ultrex 82.5 WDG $3.0 \mathrm{~kg} / \mathrm{ha}$; Bacillus subtilis as Serenade $10 \mathrm{WP}$ at $4.5 \mathrm{~kg} / \mathrm{ha}$; pyraclostrobin plus boscalid as Pristine 38 WG at $1.0 \mathrm{~kg} / \mathrm{ha}$.

$z$ Means within columns followed by the same letter are not significantly different according to Scheffe's multiple comparison test.

In 2004, there were a total of eight sprays of fungicides with the weekly schedule and five sprays with the Melcast schedule, resulting in a $38 \%$ fewer sprays per season with Melcast. In 2005, plots sprayed weekly received seven fungicide applications and those sprayed on the Melcast schedule received five applications, resulting in a 29\% reduction in sprays with Melcast. There were no significant interactions between green manure and fungicide treatment in either year (Table 3). In comparison to watermelon grown in fallow plots with no fungicide applied, the average severity of GSB was reduced in green-manured plots vs. the fallow plots averaged over all subplot treatments (53\% reduction vs. $36 \%$ reduction) in 2005 (Table 3). Yield of watermelon produced on hairy vetch green manure was higher than on fallow plots (57.8 MgHa vs. $54.4 \mathrm{MgHa}$ ) in 2004 (Table 3). In 2005, yield of watermelon produced on hairy vetch green manure vs. fallowed plots was $49.0 \mathrm{MgHa}$ and $45.4 \mathrm{MgHa}$, respectively and did not differ significantly (Table 3).

All fungicide treatments and schedules significantly reduced GSB compared to the nontreated control in both years with one exception (Table 4). On 17 August 2005, all fungicide treatments reduced GSB compared to nontreated plots, except where B. subtilis was alternated with chlorothalonil on a Melcast schedule (Table 4). There were no significant differences in either year in the reduction in GSB severity between weekly and Melcast-scheduled applications of chlorothalonil or B. subtilis alternated with chlorothalonil (Tables 3 and 4). In 2004, there was more GSB in plots sprayed with B subtilis alternated with chlorothalonil than in plots sprayed with chlorothalonil alone (Table 3). However, GSB did not differ between these treatments in 2005.

Weekly applications of chlorothalonil alone were compared to applications of chlorothalonil in alternation with pyraclostrobin plus boscalid in this study. The alternation schedule was reported to be more effective for GSB management in Georgia (18). However, no significant differences between these treatments were found in either year in our study (Table 3 ). 
I mplications for Disease Management

Watermelon growers in Maryland and Delaware have begun to use hairy vetch as a green manure in watermelon crop production on limited acreage to reduce Fusarium wilt severity (20). This study demonstrates, for the first time, that with use of hairy-vetch green manure, additional benefits may accrue in the reduction of GSB. However, a significant reduction in GSB severity by the green manure was not observed or was very small in the field trials where the levels of the disease were high, indicating suppression of GSB when hairy vetch green manure was used alone was not adequate under high disease pressure. Hairy vetch green manure, however, may be one tactic that can be used in combination with others for GSB management.

Chlorothalonil is an effective, broad-spectrum fungicide that has been widely used for several decades and remains an important tool for management of GSB and other foliar diseases on cucurbits. It is a good rotation or mixing partner within fungicide programs to manage resistance development. Our experiments were designed to evaluate several fungicide programs where chlorothalonil was a rotation partner with reduced-risk or biofungicides that minimized or reduced the synthetic fungicide used. The experiments were not designed to evaluate the individual contribution of a single fungicide or bio-fungicide within the program. Although we could not compare the effectiveness of a single component, we were able to compare programs. Only the biofungicide R. sachalinensis alternated with chlorothalonil achieved GSB reduction equal to the best treatment (chlorothalonil alternated with pyraclostrobin plus boscalid), and only in 2004 when disease level was low. Bacillus subtilis in rotation with a protectant synthetic fungicide on a weekly schedule or sprayed according to Melcast also provided a reduction in GSB. However, again the reduction usually was less than the best fungicide treatment (chlorothalonil alternated with pyraclostrobin plus boscalid). Because GSB was higher in plots sprayed with a biofungicide alternated with chlorothalonil in these studies, most growers would find the level of control unacceptable in years when disease severity is high.

Here similar management of GSB was achieved by scheduling fungicide applications with Melcast as compared to weekly sprays, confirming previous research in Maryland where similar level of control usually occurred (14). Use of Melcast resulted in a significant reduction in the number of sprays, which indicated that weekly applications often used more fungicide than was necessary to manage GSB in the mid-Atlantic region. These results were consistent with the results of previous studies that included Melcast for control of GSB, Alternaria leaf blight (Alternaria cucumerina), or anthracnose $(8,14)$. Fewer sprays of fungicides that are applied according to Melcast represent direct savings in time, labor, fuel, and equipment costs required for GSB control.

These studies demonstrate that growers who would like to reduce the amount of synthetic fungicides applied to their crop may schedule applications with Melcast or use biofungicides. However, our studies suggest that if biofungicides are scheduled with Melcast, GSB control may not be adequate.

There were no interactions in response of disease or yield to green manure and fungicide treatment in either year. This indicates that the benefits of green manure accrued to all spray programs. Also, in each trial with green manure, the hairy vetch cover crop, which produced between 4.7 and 5.2 ton/ acre biomass in our trials, provided an adequate amount of $\mathrm{N}$ for growth of subsequent watermelon crop. Use of hairy vetch green manure also increases other minor nutrients required for watermelon growth, increases levels of organic matter, and improves soil properties including increased water retention and water infiltration and saturated hydraulic conductivity $(1,4)$. It may have been these benefits that partly led to the yield increases we observed.

\section{Acknowledgments}

This research was supported in part by the US EPA Region 3 Strategic Agriculture Initiative Grants Program (X8-98397901-0), and contributions from private companies. We thank D. K. Armentrout for technical assistance and expertise and S. White-Hanson for assistance in data analysis. 


\section{Literature Cited}

1. Abdul-Baki, A. A., and Teasdale, J. R. 1993. A no-tillage tomato production system utilizing hairy vetch and subterranean clover mulches. HortScience 28:106-108.

2. Allred, A. J ., and Lucier, G. 1990. The U. S. Watermelon Industry. Staff Report No. AGES 9015. USDA, Washington, DC.

3. Bervejillo, J., Dhatt, M. S., and Gubler, W. D. 2000. Cucurbits powdery mildew fungicide trial, 1999. Fungici. Nematic. Tests (online). Report 55:242-243. doi:10.1094/FN55. The American Phytopathological Society, St. Paul, MN.

4. Candole, B. L., and Rothrock, C. S. 1997. Characterization of the suppressiveness of hairy vetch-amended soils to Thielaviopsis basicola. Phytopathology 87:197-202.

5. Egel, D. S. 2004. Evaluation of fungicides for the control of foliar diseases of watermelon, 2003. Fungici. Nematic. Tests (online). Report 59:V007. doi:10.1094/FN59. The American Phytopathological Society, St. Paul, MN.

6. Everts, K. L. 1999. First report of benomyl resistance in Didymella bryoniae in Delaware and Maryland. Plant Dis. 83:304.

7. Everts, K. L. 2002. Reduced fungicide applications and host resistance for managing three diseases in pumpkin grown on a no-till cover crop. Plant Dis. 86:1134-1141.

8. Gleason, M. L., Sisson, A. J., Masman, J . M., and Mueller, D. S. 2005. Control of anthracnose of muskmelon with fungicides in MELCAST warning system, 2004. Fungici. Nematic. Tests. Report 60:V076. doi:10.1094/FN60. The American Phytopathological Society, St. Paul, MN.

9. Guras, N., and Wehner, T. C. 2004. The genes of watermelon. Hort. Science 39:11751182.

10. Keinath, A. P. 1996. Soil amendment with cabbage residue and crop rotation to reduce gummy stem blight and increase growth and yield of watermelon. Plant Dis. 88:564-570.

11. Keinath, A. P., and Zitter, T. A. 1998. Resistance to benomyl and thiophanatemethyl in Didymella bryoniae from South Carolina and New York. Plant Dis. 82:479-484.

12. Keinath, A. P., and DuBose, V. B. 2004. Evaluation of fungicides for prevention and management of powdery mildew on watermelon. Crop Prot. 23. 35-42.

13. Keinath, A. P., DuBose, V. B., May, W. H. III, and Cantrell, J. P. 2004. Reducedrisk fungicides rotated or mixed with chlorothalonil to manage downy mildew on muskmelon, 2003. Fungici. Nematic. Tests (online). Report 59:V004. doi:10.1094/FN59. The American Phytopathological Society, St. Paul, MN.

14. Keinath, A. P., Everts, K. L., Langston, D. B. J J., Egel, D. S., and Holmes, G. J . 2007. Multistate evaluation of reduced-risk fungicides and Melcast against Alternaria leaf blight and gummy stem blight on muskmelon. Crop Prot. 26:12511258.

15. Latin, R. X., and Egel, D. S. 2001. Melcast, Melon Disease Forecaster. Purdue Coop. Ext. Publ. BP-64-W, Purdue Univ., Vincennes, IN.

16. Mills, D. L., Coffman, C. B., Teasdale, J . R., Everts, K. L., and Anderson, J . D. 2002. Factors associated with foliar disease of staked fresh market tomatoes grown under differing bed strategies. Plant Dis. 86:356-361.

17. Monroe, J. S., Tikhonova, I., and Latin, R. 1997. A model defining the relationship between temperature and leaf wetness duration and infection of watermelon by Colletotrichum orbiculare. Plant Dis. 81:739-742.

18. Seebold, K. W., and Langston, D. B. 2005. Evaluation of fungicide programs for control of gummy stem blight in watermelon, 2004. Fungici. Nematic. Tests (online). Report 60:V128. doi:10.1094/FN60. The American Phytopathological Society, St. Paul, MN.

19. Stevenson, K. L., Langston, D. B., J r., and Seebold, K. W. 2004. Resistance to azoxystrobin in the gummy stem blight pathogen documented in Georgia. Online. Plant Health Progress doi:10.1094/ PHP-2004-1207-01-RS.

20. Zhou, X. G., and Everts, K. L. 2004. Suppression of Fusarium wilt of watermelon by soil amendment with hairy vetch. Plant Dis. 88:1357-1365. 